This item was submitted to Loughborough's Research Repository by the author.

Items in Figshare are protected by copyright, with all rights reserved, unless otherwise indicated.

\title{
Integration of sustainability principles into construction project delivery
}

PLEASE CITE THE PUBLISHED VERSION

http://dx.doi.org/10.4172/2168-9717.1000116

PUBLISHER

OMICS (@ the authors)

VERSION

VoR (Version of Record)

\section{PUBLISHER STATEMENT}

This work is made available according to the conditions of the Creative Commons Attribution 4.0 International (CC BY 4.0) licence. Full details of this licence are available at: http://creativecommons.org/licenses/ by/4.0/

\section{LICENCE}

CC BY-NC-ND 4.0

\section{REPOSITORY RECORD}

Ochieng, Edward G., T.S. Wynn, Tarila Zuofa, Ximing Ruan, Andrew D.F. Price, and C. Okafor. 2019. "Integration of Sustainability Principles into Construction Project Delivery". figshare.

https://hdl.handle.net/2134/23399. 


\title{
Integration of Sustainability Principles into Construction Project Delivery Ochieng EG ${ }^{1 *}$, Wynn TS ${ }^{1}$, Zuofa $T^{1}$, Ruan $X^{2}$, Price ADF $^{3}$ and Okafor $C^{3}$
}

${ }^{1}$ School of the Built Environment, Liverpool John Moores University, Byrom Street, Liverpool, L3 3AF, England, UK

${ }^{2}$ Bristol Business School, University of the West of England, Bristol, BS16 1QY, England, UK

${ }^{3}$ Department of Civil and Building Engineering, Loughborough University, Leicestershire, LE11 3TU, UK

\begin{abstract}
Construction clients and governments recognise the significant impact the design, construction and occupation of buildings have on the environment and society. The construction industry and governments have a central role in driving the sustainable development agenda. Good sustainable design can deliver buildings with low running costs-an attribute that is highly attractive to both the society and businesses. The aim of this paper was therefore to examine the integration of sustainability principles into construction projects. The review provided key evidence of the link between sustainability and better project performance, through the integration of sustainability principles. In addition, it proposed a sustainable framework for better construction project, based on the philosophies of sustainable construction.
\end{abstract}

Keywords: Sustainability principles; Construction; Sustainable development; Sustainable building; Fragmentation

\section{Introduction}

It's been proved that global warming and climate change poses an unparalleled threat to all living beings [1]. Rapid development of the developing countries will hasten global warming and exacerbate resource problems [2]. This problem is important in the long run as most policy makers recognise (for developing countries) there are many other critical sustainable development issues that affect human welfare more immediately. Chairman of the Environment Agency stated that "Changing the way we build, produce energy and make technology more efficient must go hand in hand with the changes in behaviour and life style needed if we are not only survive climate change but thrive" [3]. Therefore, any methods that can overcome climate change are worthwhile and should be considered as part of the growing sustainability agenda [4]. In addition, the promotion of sustainable practice is by achieving the right balance between these sustainable principles; social, economic and environment in implementing construction projects. So, the need to enforce sustainable construction is significant as "what we build today will provide the built environment of the future and will influence the ability of future generations to meet their needs" [5].

In pursuing sustainable construction practice, great deal of research has been done by many researchers. For example, Hill and Bowen [6] proposed a framework for attaining sustainable construction where the major components of the framework included project environmental assessment and environmental policy. Turfil cited by Yong developed a sustainability framework for small and medium contractors to improve their performance against four dimensions of sustainability. A number of organisations are applying sustainability because of the business value in it where investigation shows over 2.4 million properties tenants are willing to pay higher base rents for greener building $[7,8]$. Thus, construction clients are increasingly requiring business consultants, contractors and suppliers to adopt sustainable policies in construction process.

Globally, buildings are responsible for approximately 40 per cent of the total world annual energy consumption [9] much of the world's energy however is currently produced and consumed in ways that could not be sustained. One way of reducing building energy consumption is to design buildings which are more economical in their use of energy. U.S. Green Building Council (USGBC) develop a green building evaluate system which is LEED (Leadership in Energy and Environmental Design) to evaluate the environmental performance of a building is an initiative for sustainability in the construction industry [10]. Construction organisations are striving to obtain this certification which shows they have addressed the environmental impact of a building [10]. It clearly shows that effective implementation of project management principles and processes helps built environment to achieve sustainability [4]. As stated by Curwell [11], "The construction industry as a whole has to rapidly come to terms with the broader environmental and social agenda that is presented by the concept of sustainable development" because the built environment affects all human activity". The primary aim of the review was to propose a framework that could be used in delivering construction projects in a sustainable way. The next section has been divided into three parts. The first part deals with sustainable development, the second and third part gives a brief overview of sustainable building and sustainable drivers. The final section of the paper draws some conclusions about sustainable principles.

\section{Sustainable development}

Sustainable development that balances social, economic and environmental goals is now on the agenda for the global construction industry [12]. As evidenced in the reviewed literature, the construction industry makes a vital contribution to the social and economic development of every country [13]. Its building sector has major impacts on the environment. It provides the basic living conditions for the sustainability and development of human life on Earth [13]. Though, the built environment currently has huge impact on the environment, raw materials and also the physical and economic health of individuals and communities. Sustainable construction can contribute to the achievement of sustainable development themes which is the "triple bottom line" by embracing the following objectives [14]:

*Corresponding author: Ochieng EG, Faculty of Technology and Environment School of the Built Environment, Liverpool John Moores University, Byrom street, Liverpool, L3 3AF, UK, Tel: 44 (0151) 2312859; E-mail: e.g.ochieng@ljmu.ac.uk

Received December 10, 2013; Accepted January 17, 2014; Published January 26, 2014

Citation: Ochieng EG, Wynn TS, Zuofa T, Ruan X, Price ADF, et al. (2014) Integration of Sustainability Principles into Construction Project Delivery. J Archit Eng Tech 3: 116. doi:10.4172/2168-9717.1000116

Copyright: @ 2014 Ochieng EG, et al. This is an open-access article distributed under the terms of the Creative Commons Attribution License, which permits unrestricted use, distribution, and reproduction in any medium, provided the original author and source are credited. 
- being more profitable and competitive;

- delivering building and structures that provide greater satisfaction, well-being and value to customers and users;

- respecting and treating its stakeholders more fairly;

- enhancing and better protecting the natural environment;

- minimising its consumption of energy (especially carbon-based energy and natural resources.

In 1994, sustainable construction was defined as the creation of healthy built environment based on resource-efficient and ecological based principles [4]. Since then, the industry faces a lot of different interpretation of sustainability and number of problems or doubt on how sustainability could be achieved. Bruntland Report then come out with a definition as "...meeting the needs of the present without compromising the needs for the future generation". The definition underlay a variety of efforts to ensure a good quality of life for the future generations. Sustainable construction not only refers to the buildings but also including the processes or activities to build them. DETR [14] proposed ten themes for action with the aim of providing individual firms with practical pointers for achieving sustainable construction as shown in Table 1.

As sustainable construction initiative continues to develop and gain popularity, critics and supporters alike are constantly evaluating the progress [8]. By means of sustainability, the evaluation must include more than the immediate investors or tenants of the buildings but also consider suppliers, local community in which the building resides and other stakeholders.

In construction practice, sustainable construction refers to the different method used in the construction project which bring less harm to the environment, benefit the society and increase profit of the company [15]. It is a well-known fact that successful delivering of projects in the construction industry depends on effective project management. Whitty [16] considers project management to be a complex emergent behaviour. Whitty emphasises that: "bring evolutionary science and project management together and may get some pretty interesting results". The UK construction Industry is at present suffering from a number of problems. As noted below, these issues have been highlighted by many researchers $[6,17,18]$. The following have been identified as key barriers:

Ten Themes for Action Design for minimum waste Re-use existing building

Think about using recycle materials. Renovate to improve their sustainability if possible.

Aiming for lean construction Continuous improvement and high quality work.

Minimise energy in construction and usage Beware of energy consumption during construction processes and building energy efficient solutions.

\begin{tabular}{l|l} 
Eliminate pollution & Adopting Environmental Management System
\end{tabular} (EMS) or International Standard Organisation (ISO)

\begin{tabular}{l|l}
$\begin{array}{l}\text { Preserve and enhance } \\
\text { Biodiversity }\end{array}$ & Throughout the construction process. \\
\hline
\end{tabular}

\begin{tabular}{l|l} 
Minimise water usage & Efficiency use of water in construction and
\end{tabular} building.

Social Respect $\quad$ Responsive to local community and workforce.

\begin{tabular}{l|l} 
Setting targets & Benchmarks own performance with others
\end{tabular} project and set targets for continuous improvement.

Source: DETR (2000, p.20)

Table 1: Ten themes for action (Building a Better Quality of Life).
Financial to address sustainability: One of the main potential barriers for the implementation of sustainable construction is cost. Critically, the increased first cost associated with sustainable buildings is a major barrier for owners to pursuing sustainable building objectives [19]. Costs initially increase by an average of 2 to 7 per cent for sustainable building over an ordinary building and only some projects can recover overall net costs in a short period [6]. Some clients noted that the cost for providing environmental sustainable building and developments is significantly higher than for standard schemes and most were not convinced that there is a potential demand for such buildings [18]. Moreover, current financial crisis and the global recession continue to put pressure on projects leading to moderate construction price deflation. One of the biggest concerns is contractor finances and working capital [17]. Many contractors find it difficult to maintain their cash flow for operations and have sufficient resources for expansion of working capital. These barriers still can be overcome by changing the view of stakeholders from cost to value and from shortterm to long-term.

Lack of considerations from client and stakeholders: From the reviewed literature, it has been suggested that in some cases, clients lacked on the information they needed to make choices about which development options would be more or less sustainable [18]. Sourani and Sohail [20] mentioned that low level of awareness and understanding about sustainability issues not only exists on people working in public client organisations but also among the stakeholders organisations and groups such as contractors, end user and funding organisations. This might be the problem attributed to the lack of training on sustainability issues by several institutions and professional bodies, lack of clear structure and guidance and the nature of relevant codes of practice in terms of being advisory rather than mandatory.

Insufficient knowledge and skills about sustainability: Although there are assessments tool and indicators already in place, question is on without clarity and when to use them and by whom, is creating confusion and burden among practitioners [20]. There is a need of developing simple but wide-ranging tools and techniques to deal with situations where sustainability needs to be assessed. Addressing these problems will require significant and sustained investment in education and training alongside increased publicity [21]

Insufficient regulations by government: The policies, regulations, incentives and commitment by leadership may not be sufficient enough to move towards the realisation of sustainable developments. Sourani and Sohail [20] stated that value added tax (VAT) was enacted on building refurbishment but not on new building. Katie [18] supported this statement by emphasising refurbishment was the better option from the environmental point of view than a new build. Even though there are many regulations and government policies in place to support sustainability issues, it was mentioned that such regulations and policies may be insufficient [20]. There is a need therefore of a more mandatory role in order to better address sustainability.

Resistance to change: Addressing the term sustainability requires new ways of thinking, practices and attitude. Therefore, it requires change. As companies which have been in the industry for a long term when implementing new initiative; there is a resistance to change. In client organisations, problems arise due to lack of leadership, restriction on funding and lack of guidance.

Fragmentation: Another barrier to promote sustainable construction is because of the industry's size and fragmentation. In Egan's report-Rethinking Construction, it has been noted that this level 
of fragmentation has both strength and weaknesses. On the positive view, it has provided to deal with highly variable workloads. Whereas the negative view, the extensive use of subcontracting has brought contractual relations to the front and prevented continuity contract to work as a team [22]. Egan [22] further suggested that partnering and framework agreement can be used as tools to tackle fragmentation to improve performance through agreeing mutual objectives and encourage sustainable construction. Sustainable construction does not simply mean to continue its business growth but also need to achieve the principles of sustainable development, which mean it may need, in some cases to stop growing or grow in different ways [23]. With construction business reference, sustainability is about achieving a win-win outcome for contributing to the improved environment and advanced society and in the meantime gaining competitive advantages and economic benefits for construction companies [15].

Sustainable building: Over the past decades, sustainable building also known as green building (GB) emerged as a new building philosophy, encouraging environmental friendly resources, maximising recycling and reduces waste production and emphasis on indoor environmental quality [24]. It approach to the built environment involves a holistic approach to the design of the building [12]. Khalfan [12] mentioned that, although new technologies are increasing being developed to cope with the current practice in building greener structures, the basic priorities for sustainable buildings are to reduce the overall impact of the built environment on human health and natural environment. It is worth noting that, the success of a sustainable building depends on the quality and efficiency of the green systems installed. What surprises many people unfamiliar with this design movement is that good sustainable buildings often cost little or no more to build than conventional designs [12].

Cost benefit for sustainable building: The perceived extra cost of sustainable building, coupled with the perceived low value of social quality has generally prevented action to date, except by the most committed. However, a significant aspect of growing interest in green building and sustainable design can be attributed to the recognition by clients that there are direct economic benefits from green buildings [25]. A number of studies from around the world demonstrate a pattern of greener buildings able to gain tenants and investor interest and to command higher rents or sale prices [26]. Similarly, RICS [27] suggested that contrary to public perception designing in environmentally efficient specifications does not necessarily result in higher capital cost.

\section{The Effectiveness of the drivers implemented}

In considering the effectiveness of the drivers that have been implemented to achieve sustainable construction practices, it would perhaps be wise to consider our moral views towards the environment and also the process of change. The following have been identified as key drivers:

Ethics and behavioural change: Ethics is the branch of philosophy that investigates morality and the ways of thinking that guide human behaviour. The philosophy of ethics requires that we take a step back from this experience and reflect critically on it. Steg and Vlek [28] suggested that when environmental behaviour has been selected and its casual factors identified, intervention strategies can be targeted on the relevant factors. In addition, Steg and Vlek [28] recommend that economic analysis in ethics rests on serious misunderstanding between 'wants' or 'preferences' and 'beliefs' or 'values'. However, sustainable economics offer different way to view about economics and the environment as sustainable economics is concerned with the resources rate flowing through the economy [29]. Therefore, it makes sense to develop a sustainable economic system that uses the resources at the rate the earth can sustain if human realise natural resource originate from the earth.

Legislation and regulation: Cocklin suggested that regulatory analysis and regulation theory provide appropriate foundations for the analysis of environmental problem and encourage firms to invest in green technologies. Tam et al. [30] and Fraj-Andres [31], indicated that fines and penalties for non-compliance to regulations will lead to more cautious attitude to environmental compliance. Recent evidence suggests that [32] provide different view, criticising that environmental regulations go too far mentioning that government fail to consider economics and that these regulations never consider the overall social benefit provided may be worth the 'cost' to the environment. Finally, Shen [15] stated that stricter environment policies are needed as drivers. From the above review, it can be observed that sustainable construction is based on best practices which emphasize long term affordability, quality and efficiency [33].

\section{Conclusion: The Way Forward}

As revealed from the reviewed literature, a number of sustainable factors determine the integration of sustainable principles into construction projects. The evidence suggests that these factors need to be considered for the successful application of sustainable, ensuring sustainable improvements in construction project. It has been shown that the integration of sustainable principles into construction project can lead towards sustainable construction and improve project delivery.

The literature reviewed indicated that LEED is a concise framework that provides building owners a measureable green building design, construction, and maintenance solutions. Accordingly, these findings suggested that LEED has been designed with the three sustainable principles in mind. The review demonstrated that environmental tools such as LEED could directly affect the overall performance of a construction project. However the core findings for this review are the cost of getting the environmental certification. It is worth noting that clients tend to aim for the minimum rating to minimise capital cost and expand profit. Therefore, the findings show that contractual obligation, regulations and cost benefit are the push for practitioners to aim for higher environmental certification.

The results of the literature reviewed; show that sustainable factors can be used to engage into construction project, resulting in the successful management and delivery of environmental construction project. The literature reviewed however demonstrated that not all sustainable factors are applicable to each case of construction project due to the 'variable' nature of construction industry. This finding confirms that understanding and knowledge of the sustainable factors is necessary to ensure their successful application to construction project and most importantly the drivers of using it.

The research identified that the incentives and strategies, regulations and change as the success criteria to move towards sustainable construction. Practitioners tend to use the strategies implemented by the government only when incentive or benefit was in place. Furthermore, the influence of sustainability is significant to change people mind-set about sustainable construction and buildings. Taken together, the results reaffirmed that the drivers are in need to ensure sustainable construction delivery and subsequently improve project performance. The conclusion drawn from this review on success criteria implementation of sustainable principles into construction 
project was that sustainable construction can be successfully implanted when people recognised the benefit and incentive in it.

The review identified that with the integration of sustainable principles, success towards sustainable construction were evident. Findings of the literature reviewed suggest that development of a 'framework' for managing sustainable project delivery, is based on effective sustainable principles. The secondary data of the research suggest that there is a link between sustainable principles and success in sustainable construction project. The results, as summarised in Figure 1 , indicate that the integration of sustainable initiatives fall under four themes:

- client consideration and understanding of sustainability

- environmental responsible contractors and suppliers

- integration of sustainable principles

- success criteria for sustainable construction

Consideration and understanding from client is essential for the integration of sustainable principles into construction project. Right contractors and suppliers must be selected to ensure a sustainable project delivery. It is worth noting that, not all sustainable factors are applicable to every type of project, due to the complexity nature of the construction industry. It was found that the integration of sustainable principles in construction project is significant to manage the current environment issue and attain significant improvements in performance. What the construction industry must consider is the integration of sustainable principles into construction project and sufficient trainings from respective construction industry bodies such as Royal Institution of Chartered Surveyor (RICS) and Chartered Institute of Building (CIOB) to ensure their correct application.

\section{Recommendations for further research}

The review has achieved its aim of determining the sustainable factors within the construction projects, allowing a sustainable construction framework to be proposed for managing construction project.

This review has thrown up many questions in need for further investigation. It is recommended that further research be undertaken in the following areas:

- There is a growing client demand for sustainability not only within the construction process but also day to day business. Currently, there is a lack of standardised regulation and strategies to address sustainability in construction project. A number of future studies are therefore apparent, to aid the project delivery team in understanding the correct procedure for the application of sustainable principles in construction

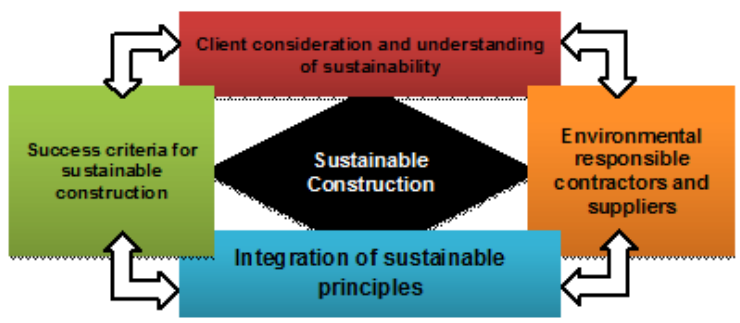

Figure 1: Proposed sustainable construction framework.

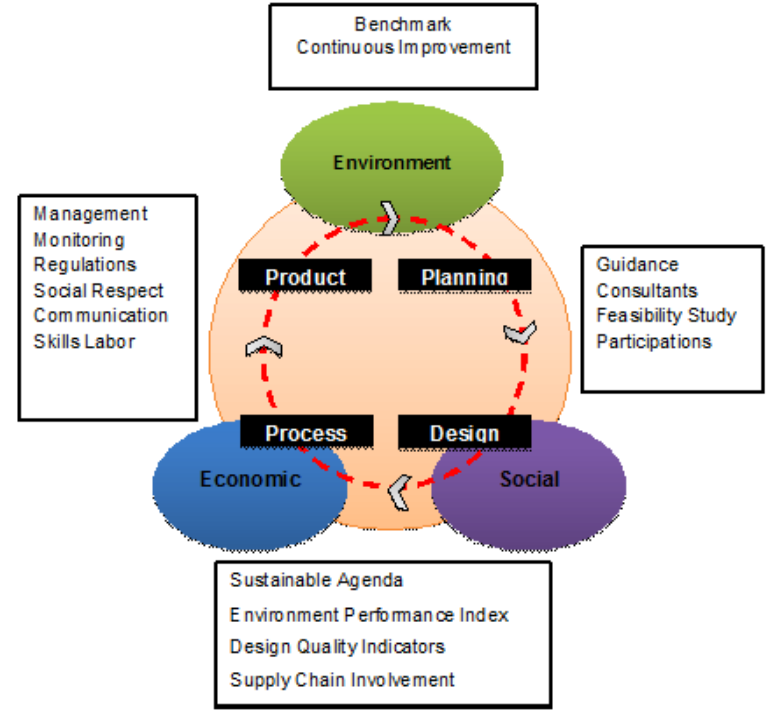

Figure 2: Integration of the triple bottom lines into construction processes.

process. The following Figure 2 was developed to show the integration of triple bottom line into construction process

- It was established that progressive training for construction professional is significant for the successful application of sustainable principles in construction project. Further research is required to establish whether training for construction professionals on sustainable construction would increase the sustainable practice within the construction industry.

\section{References}

1. Kappelle M, Vuuren MMI, Baas P (1999) Effects of climate change on biodiversity: A review and identification of key research issues. Biodivers Conserv 8: 1383-1397.

2. Murota $Y$ (1996) Global warming and developing countries-The possibility of a solution by accelerating development. Energ Policy 24: 1061-1077.

3. Harman J (2007) Construction industry could be next victim of climate change

4. Agyekum-Mensah G, Knight A, Coffey C (2012) 4Es and 4 Poles model of sustainability: Redefining sustainability in the built environment. Struc Surv 30 426-442.

5. Pitt M, Tucker M, Riley M, Longden J (2008) Towards sustainable construction: promotion and best practices. Construction Innovation: Information. Process Management 9: 201-224.

6. Hill R, Bowen P (1997) Sustainable construction: principles and a framework forattainment. Constr Manag Econom 15: 223-239.

7. Miller N, Spivey J, Florance A (2008) Does green pay off?. J Real Estate 14: 385-400.

8. Presley A, Laura M (2010) Benchmarking for sustainability: an application to the sustainable construction industry. Benchmarking: Int J 17: 435-451.

9. Omer AM (2008) Energy, environment and sustainable development. Renew Sust Energ Rev 12: 2265-2300.

10. Tsai CY, Chang AS (2011) Framework for developing construction sustainability items: the example of highway design. J Clean Prod 20: 127-136.

11. Curwell SR (1998) An introduction to the BEQUEST Project, Presented at seven international workshops in the EU, organised by SC as part of the BEQUEST project - Manchester, Amsterdam, Turin, Helsinki, Vienna, Milton Keynes, Florence. 1998-2000.

12. Khalfan MMA (2002) Sustainable development and sustainable construction. A literature review for C-SanD. 
Citation: Ochieng EG, Wynn TS, Zuofa T, Ruan X, Price ADF, et al. (2014) Integration of Sustainability Principles into Construction Project Delivery. J Archit Eng Tech 3: 116. doi:10.4172/2168-9717.1000116

Page 5 of 5

13. Xiaoling Z, Wu Y, Shen L, Skitmore M (2013) A prototype system dynamic model for assessing the sustainability of construction projects. Int $\mathrm{J}$ Project Manage 32: 66-76.

14. DETR (2000) Building a better quality of life: A Strategy for more sustainable construction. Department of the Environment, Transport and the Regions: London.

15. Shen LY, Tam VWY, Tam L, Ji YB (2010) Project feasibility study: the key to successful implementation of sustainable and socially responsible construction management practice. J Clean Prod 18: 254-259.

16. Whitty J (2013) Thinking in slow motion about project management. In: Novel approaches to organisational project management research: Translational and transformational. Advances in Organisation Studies (29) Copenhagen Business School Press, Copenhagen, Denmark 95-116.

17. Kubba S (2012) Handbook of Green Building Design and Construction. Leed Breeam and Green Globes.

18. Katie W, Dair C (2006) What Is stopping sustainable building in England? Barriers experienced by stakeholders in delivering sustainable developments. Sustain Dev 15: 135-147.

19. Lapinski AR, Horman MJ, Riley DR (2006) Lean processes for sustainable project delivery. J Constr Eng Manage 132: 1083-1091.

20. Sourani A, Sohail M (2011) Barriers to addressing sustainable construction in public procurement strategies. Proceedings of the ICE-Engineering Sustainability 164: 229-237.

21. Marchman M, Clarke SN (2011) Overcoming the Barriers to sustainable construction and design through a cross-reference of west coast practices. Clemson, South Carolina: Associated Schools of Construction.
22. Egan SJ (1998) Rethinking Construction: The Report of Construction Task Force. Department of Trade and Industry.

23. Du Plessis C (2002) Agenda 21 for sustainable construction in developing countries, Pretoria, South Africa: CSIR Building and Construction Technology.

24. Wang W, Zmeureanu R, Rivard H (2005) Applying multi-objective genetic algorithms in green building design optimization. Build Environ 40: 1512-1525.

25. Halliday S (2008) Sustainable construction. (1stedn), Butterworth Heinemann.

26. USGBC (2013) United States Green Building Council.

27. RICS (2011) Royal institute of chatered surveyor: A Vision For Sustainability, London: RICS HQ.

28. Steg L, Vlek C (2009) Encouraging pro-environmental behaviour: An integrative review and research agenda. J Environ Psychol 29: 309-317.

29. Dyllick T, Hockerts K (2002) Beyond the business case for corporate sustainability. Bus Strat Environ 11: 130-141.

30. Tam VWY, Tam CM, Shen LY, Zeng SX Ho CM (2006) Environmental performance assessment, perceptions of project managers and the relationship between operational and environmental performance indicators. Construc Manag Econom 24: 149-166.

31. Fraj-Andres E, Martinez-Salinas E (2009) Factors affecting corporate environmental strategy in Spanish industrial firms. Bus Strat Environ 18: 500 514

32. Jardins D (2001) Environmental ethics: An introduction to environmental philosophy. (3rdedn),Wadsworth Group, Thomson Learning Inc

33. WCED (1987) Our Common future (the Brundtland Report).
Citation: Ochieng EG, Wynn TS, Zuofa T, Ruan X, Price ADF, et al. (2014) Integration of Sustainability Principles into Construction Project Delivery. J Archit Eng Tech 3: 116 doi:10.4172/2168-9717.1000116
Submit your next manuscript and get advantages of OMICS Group submissions

Unique features:

- User friendly/feasible website-translation of your paper to 50 world's leading languages

- Audio Version of published paper

Digital articles to share and explore

Special features:

300 Open Access Journal

25,000 editorial team

21 days rapid review process

Quality and quick editorial, review and publication processing

Indexing at PubMed (partial), Scopus, EBSCO, Index Copernicus and Google Scholar etc

Sharing Option: Social Networking Enabled

- Authors, Reviewers and Editors rewarded with online Scientific Credits

Better discount for your subsequent articles

Submit your manuscript at: http://www.editorialmanager.com/acrgroup/ 